\title{
O AVESSO E O DIREITO: CONCUBINATO E CASAMENTO NUMA COMUNIDADE DO NOROESTE PORTUGUÊS ${ }^{1}$
}

\author{
Ana Silvia Volpi Scott ${ }^{2}$ \\ NEPO UNICAMP
}

\begin{abstract}
RESUMO: A literatura especializada sobre família tem produzido, num leque variado de abordagens, um número significativo de estudos, incluindo a Demografia Histórica. Em Portugal, uma ampla documentação referente às visitas pastorais, de vários arcebispados, vem se constituindo numa fonte importantíssima de estudos, permitindo analisar e compreender fenômenos ligados ao casamento, aos nascimentos legítimos e ilegítimos, às questões de transferência de patrimônio Este trabalho tem como objetivo explorar diferentes fontes e cruzar as informações provenientes de registros paroquiais, rol de confessos, testamentos e fontes fiscais, visando analisar a nupcialidade e a reprodução social das famílias e dos indivíduos, verificando as condições em que ocorriam denúncias aos visitadores.
\end{abstract}

\section{THE BACK AND THE FRONT: friendship and marriage in one portuguese community}

Palavras-chaves: documentação, visita pastoral, denúncia, casamento, concubinato

ABSTRACTS: The specialized literature about family is producing, in varied approaches, a significant number of studies, including some in Historical Demography. In Portugal there is a great documentation about bishops pastoral visitation, and these materials are an important source for different studies affording the opportunity of analyzing and understanding the phenomena of legal and illegal birth, and the questions of heritage transmission. This paper intends to explore different sources and cross their data in order to obtain reports coming from parochial reports, with the aim of analyzing marriage, family and individual social reproduction, and the conditions under which occurred the denunciations to the visitors.

Key-words: documentation, pastoral visit, denunciation, marriage, concubinage

$O$ ato de dois indivíduos unirem-se, ou não, através do vínculo perpétuo e indissolúvel do sagrado laço do matrimônio, implica numa série de constrangimentos e opções - familiares e pessoais - que nem sempre podem ser suficientemente conhecidos, na medida em que, nem sempre está disponível ao investigador fontes que permitam apreender esta rica e complexa teia de relações.

O casamento e a família representam um inesgotável manancial de questões e problemas. Especialmente a partir da exploração sistemática de fontes que permitam a reconstrução dos comportamentos relativos à união social e religiosamente reconhecida.

Toda uma literatura especializada tem sido

\footnotetext{
1 Artigo recebido para publicação em outubro de 2001 aceito em junho de 2002.

${ }_{2}^{2}$ Endereço para correspondência: Ana Silvia Volpi Scott NEPO UNICAMP - Caixa Postal 6166 - CEP 13081-970 Campinas E mail-asvscott@uol.com.br
}

produzida, desde pelos menos há três décadas, tratando a família como um campo de investigação específico e adotando inclusive, conceitos e métodos emprestados de outras disciplinas para enriquecer suas perspectivas de análise.

Desta forma um leque variado de abordagens floresceu. Por exemplo, o estudo dos seus comportamentos demográficos, nas diferentes áreas geográficas, passando pelos diversos grupos sociais, e como estes variavam ao longo do tempo.

Paralelamente ao desenvolvimento da demografia familiar, os investigadores ultrapassaram os limites da família biológica e partiram para a análise do agregado doméstico. Integrou-se, desta forma, o indivíduo e a família num universo mais alargado, constituído pelo espaço da vicinalidade e das relações interpessoais e interfamiliares.

Buscava-se perspectivar as duas esferas que compunham o quotidiano dos indivíduos, das famílias 


\section{Ana Silvia Volpi Scott}

e da comunidade. Em outras palavras, o público e o privado.

Esta é uma abordagem interessante a que os historiadores da família vêm se dedicando, a interseção da vida privada e pública, explorando as relações familiares no nível da comunidade mais ampla em que estavam inseridas (Lynch, 1994).

Uma outra vertente a considerar é a que pretende compreender a situação dos indivíduos que não estavam integrados (temporariamente ou permanentemente) em famílias ou nos seus modelos socialmente reconhecidos, procurando, através desta perspectiva, dar uma imagem mais realista e equilibrada da familia, tanto no passado como no presente (Lynch, 1994).

Podendo integrar esta abordagem, estariam os trabalhos que analisam o fenômeno da ilegitimidade, entendida como reprodução biológica que escapa ao controle imposto através das regras religiosas e sociais estabelecidas nas comunidades ocidentais. $O$ tema surge de forma privilegiada naquelas investigações que utilizam como fonte básica os registros paroquiais (especialmente os de batizado).

Neste âmbito, a produção de incontáveis trabalhos traz comportamentos dos mais variados, das áreas em que a ilegitimidade é praticamente inexistente até aquelas em que os nascimentos fora do casamento têm um peso muito significativo no cômputo geral dos batizados.

Uma amostra da diversidade de situações, quanto à ilegitimidade na Europa, está nos dados apresentados por Michael Flinn (1981). Embora a publicação tenha mais de quinze anos e, portanto esteja desatualizada em relação à investigação mais recente, ainda é um útil indicador de como este fenômeno se manifestou em muitos países.

Os dados coletados englobam diversas áreas e países da Europa: Inglaterra, França, Alemanha, Escandinávia, Espanha(Flinn, 1981). A conclusão que se pode tirar é que a variação de comportamentos é muito grande, com taxas de ilegitimidade diversificadas não só entre os países, mas nas diferentes regiões de cada país.

Tem-se ainda, para as mesmas áreas, indicações sobre outro fenômeno importante que é a concepção pré-nupcial. Observa-se uma grande variação, dos $6 \%$ para a França até os $20 \%$ a $30 \%$ para Inglaterra e Alemanha, e ainda com variações inter- nas remarcáveis (Flinn, 1981).

Analisar este tipo de desvio comportamental é muito mais fácil para o investigador, uma vez que o registro de nascimentos ilegítimos ou originários de concepções pré-nupciais é o resultado concreto da união sexual fora dos laços do matrimônio.

Torna-se bastante mais complexa para o investigador a tarefa de "apanhar" as relações ilícitas entre homens e mulheres que não geraram descendência.

Eventualmente, é possível rastear alguns casos, mas a maioria das relações fora do casamento pode ficar irremediavelmente perdida. Dentro das lógicas sociais é compreensível que assim seja. $\mathrm{O}$ espaço da transgressão, do desvio da norma, da subversão dos papéis é difícil de ser apreendido, porque não há desejo ou interesse em publicizá-lo.

Portanto, é fundamental para o investigador descobrir e analisar fontes que levantem o véu que encobre estes comportamentos, que não eram assim tão marginais quanto se poderia esperar, nos lugares onde a Igreja Católica era onipresente.

$\mathrm{E}$, tendo isso em conta, alguns historiadores adotavam, anos atrás, uma divisão que separava a Europa do Norte da Europa do Sul (Chaunu, 1986); e ela não convence, já que através da simples observação dos resultados apresentados por Flinn, sobre as taxas de ilegitimidade e concepçcōes pré-nupciais, não é possível aceitar as noçc̃es generalizantes de que a primeira (Europa do Norte) seria mais permissiva, e a segunda (Europa do Sul) mais controlada do ponto de vista dos impulsos sexuais.

O caso específico de Portugal, um país da Europa do Sul, com indiscutível aceitação da doutrina da Igreja Católica, constitui um bom exemplo da fragilidade das generalizações quando confrontadas com casos concretos.

$O$ estudo da ilegitimidade em Portugal tem revelado que o fenômeno apresenta fortes variações no âmbito nacional, com trabalhos evidenciando que a geografia da ilegitimidade para o Antigo Regime português está longe de se encontrar definida (Amorim, 1995). Embora a maior parte das publicaçōes tenha tratado da região norte de Portugal, aparecem variações do comportamento demográfico das populações portuguesas com relação à ilegitimidade em outros pontos. ${ }^{3}$ 
Um artigo recente procurou fazer uma sintese dos autores que têm investigado as temáticas ligadas ao abandono de crianças, à ilegitimidade e concepções pré-nupciais em Portugal. Quanto à ilegitimidade, os resultados reunidos reafirmam a grande diversidade das percentagens de batizados de crianças ilegítimas, variando de $2 \%$ a $40 \%$, consoante a região e o período. Do mesmo modo ficou patente a variabilidade das concepções pré-nupciais (Śá, 1996).

Por outro lado, uma abordagem que privilegie o relacionamento dos sexos fora do âmbito do sacramento do matrimônio deverá revelar muito, especialmente porque fontes que desvendem esses comportamentos nem sempre estão disponíveis.

Portugal, felizmente neste campo, tem uma posição privilegiada. Mais precisamente, algumas regiões portuguesas dispõem de uma documentação valiosa para o tratamento das formas alternativas de união e relacionamento sexual entre o homem e a mulher. São os testemunhos deixados pelas Visitas Episcopais realizadas regularmente até inícios do século XIX, embora com maior incidência entre os séculos XVII e XVIII.

O Concílio Tridentino impôs, como uma das obrigações fundamentais aos bispos, a visita anual a todas as freguesias de seu bispado. Apesar dessa diretriz ter sido fixada de forma geral para os países católicos, as visitas portuguesas apresentam diferenças fundamentais com relação às congêneres de outros paises da Europa católica.

Joaquim Carvalho, um dos autores que mais se dedicou à análise deste mecanismo de controle criado pela Igreja Católica, defende a hipótese de que a originalidade portuguesa não se deve a uma concepção pastoral original por parte do episcopado, mas a fatores externos ao corpo doutrinal e jurídico da Igreja católica universal. Ele argumenta que a atividade visitacional pós-tridentina foi limitada em outros estados, na mesma época, devido aos condiconantes jurisdicionais impostos pelo poder secular às ações de caráter judicial contra os leigos por parte da Igreja. Para Carvalho, são as modalidades nacionais de implementação de formas limitativas da

\footnotetext{
${ }^{3}$ Autores abordaram o fenômeno da ilegitimidade, a partir de perspectivas, como a da Demografia Histórica, Antropologia, História, Sociologia (Albino, 1986; Amorim, 1987; Boisvert, 1988; Brettell, 1985; 1986; 1988; 1991; Brettell \& Metcalf, 1993; O'Neill, 1984;1985a; 1987; Pina Cabral, 1984; 1989; Sá, 1996).
}

jurisdição eclesiástica e de mecanismos alternativos do controle social que explicam as diferentes modalidades de visitas pastorais que se encontram na Europa pós-tridentina (Carvalho, 1988) ${ }^{4}$.

Em outras palavras, as visitas portuguesas diferenciam-se das demais do mundo católico do Antigo Regime devido à jurisdição episcopal sobre os leigos, no que dizia respeito aos pecados públicos.

Alguns autores têm tratado sistematicamente este importantíssimo acervo documental, constituído pelas visitas pastorais e mostram toda a peculiaridade e riqueza destas fontes, e acima de tudo, apontam a extraordinária contribuição que podem dar para o estudo da história da família em Portugal. Deste ponto de vista, são fundamentais aqueles trabalhos que procuram evidenciar os desvios comportamentais, especialmente para o caso da Diocese de Coimbra no Antigo Regime (Carvalho 1985; 1988; Carvalho \& Paiva, 1985; 1989b; Paiva 1989). Além disso, a elaboração e publicação de um repertório sobre as visitas realizadas naquela diocese permitiram a divulgação de fontes importantes (Carvalho \& Paiva, 1985).

Entretanto, a alusão às visitas pastorais não é nova em Portugal, variando, isto sim, o tipo de abordagem dada às mesmas. A referência mais antiga encontrada é de meados da década de sessenta num artigo intitulado "Os livros de Visitas Pastorais" (Pereira, 1965). Seguiram-se outros trabalhos já na década de setenta (Soares, 1972; Pereira 1973; Santos; 1979). Nos anos 80 e 90 apareceram muitos estudos que se ocuparam da análise das visitas pastorais ${ }^{5}$ mas, a grande concentração se dá para a diocese de Coimbra e para o Arcebispado de Braga (Afonso, 1985; Bethencourt, 1987; Carvalho, 1985; 1988; Carvalho \& Paiva, 1985; 1989a; Paiva, 1991; 1993a; 1993b; Pereira, 1965; 1973; 1980; 1992; Rodrigues, 1985; Santos, 1979; Soares, 1972; 1978; 1981; 1983; 1989; 1996; 1997; Vale, 1997; Vasconcelos, 1986).

O acervo disponível de visitas pastorais para o Arcebispado de Braga forma, outro conjunto documental tão valioso como o de Coimbra, e vêm sendo

\footnotetext{
${ }^{4} \mathrm{O}$ artigo fundamental para a análise dos exemplos de visitas pastorais e a especificidade portuguesa foi escrito em 1988 por Joaquim Carvalho; mostra a originalidade do caso portugues, e compara com diversos parses.

${ }^{5}$ Estas referências não têm a intenção de esgotar os estudos sobre o tema; apenas arrolar o conjunto de trabalhos recolhidos durante a investigação e pontualmente registrados.
} 


\section{Ana Silvia Volpi Scott}

sistematicamente explorado por Franquelim Neiva Soares que tem extensa obra sobre o tema das visitas (Soares, 1972; 1978; 1981; 1983; 1989; 1996; 1997). Vale ressaltar que em 1986, tal como para Coimbra, foi publicado um inventário sobre a documentação dessa natureza, existente no Arquivo Distrital de Braga/Arquivo da Universidade do Minho (Vasconcelos, 1986).

No caso das visitas pastorais referentes ao Arcebispado de Braga, explorou-se a documentação ${ }^{6}$ composta pelo assim chamado Roteiro dos Culpados.

De maneira sumária, pode-se dizer que o Roteiro dos Culpados, da circunscrição visitacional, se estendia diacronicamente ao longo das décadas, e era um simples rol de todos os pronunciados em cada freguesia, indicando-se, a partir de certa data, a profissão e a multa (Soares, 1985).

No Arquivo Distrital de Braga encontra-se no códice 197-21 o Roteiro dos Culpados da Visita da $3^{\mathrm{a}}$ Parte de Vermoim e Faria (uma das circunscrições em que se dividia o arcebispado de Braga), que reúne todos os pronunciados daquela área, entre os anos de 1730 e 1835.

A intenção ao explorar esta fonte foi o cruzamento de informações provenientes do roteiro dos culpados, com uma ampla base de dados (registros paroquiais, róis de confessados, testamentos, fontes fiscais etc.) de que se dispunha, para uma das freguesias do Conselho de Guimarães, integrada naquela circunscrição.

São Tiago de Ronfe, foi escolhida para servir de esiudo de caso $^{7}$, tendo em vista uma tese de doutoramento apresentada ao Instituto Universitário Europeu (Florença-Itália).

Dispondo daquelas fontes, tem-se como objetivo central do estudo mais amplo a análise da nupcialidade e da reprodução social das famílias e dos indivíduos. Paralelamente, pretende-se analisar as diferentes estratégias de sobrevivência, a partir de mecanismos que interligavam o casamento, o ce-

\footnotetext{
${ }^{6}$ Tese de Doutorado de Soares (1997).

7 Agradecimentos à Profa. Norberta Amorim que sugeriu a freguesia de São Tiago de Ronfe como boa escolha para a realização do projeto e disponibilizou a base de dados da paróquia de Ronfe, reconstituída, corrigida e ampliada através de outras fontes, provenientes do fundo paroquial, do acervo do Arquivo Alfredo Pimenta, Arquivo Distrital de Braga, Sociedade Martins Sarmento.
}

libato, a transmissão de autoridade/bens e emigração.

Configuraram-se como aspectos também essenciais a serem abordados, os comportamentos que se desviavam do padrão familiar, encorajado e promovido pela Igreja Católica. Estes estariam representados pelo nascimento de significativo número de crianças ilegítimas, geradas não apenas por via de relacionamentos amorosos fortuitos, mas como resultado de uniões consenșuais estáveis. Tais uniões levariam algumas mulheres à maternidade ilegítima em três, quatro, cinco, seis e até mesmo sete gravidezes e, ao que tudo indica, de um mesmo parceiro.

$O$ intuito fundamental dessa análise é exatamente conhecer, e mais do que isso, compreender a componente social representada pelos elementos que não estavam enquadrados numa vida familiar estruturada de acordo com as normas vigentes.

Esses nascimentos evidenciavam uma das facetas mais visíveis dos comportamentos marginais. Eram os resultados concretos de certo número de relações fora do casamento, muito embora, aquelas que não deixassem frutos, fossem difíceis de serem estimadas (Grieco, 1994).

A apreensão, deste conjunto de relações ilícitas, só é possível através das informações constantes na documentação gerađa através das visitas pastorais realizadas nas paróquias portuguesas. Aí sim, no caso da freguesia de Ronfe, ter-se-ia uma amostra representativa dos desvios e pecados morais mais comuns, através do elenco de indivíduos citados no roteiro dos culpados e que seriam identificados e selecionados dentro da base de dados geral organizada.

A evidência dos dados recolhidos, não só para a freguesia de Ronfe, mas para todas as áreas com esta documentação conservada, mostra que, muito embora a Igreja lutasse para zelar pela manutenção dos bons costumes, os delitos comportamentais ocorriam de forma frequiente. Isto fica explícito no trecho da pastoral que circulou no início do século XVIII, quando era Arcebispo de Braga D. Rodrigo de Moura Teles:

"muitos excessos, faltas, erros,
escandalos, culpas e omissoins assim nos
eclesiasticos como nos seculares e ainda
nos mesmo parochos de que se seguem 
muitas offensas a Deos (...) devemos por obrigassão de nosso offisio pastoral ocorrer a estes damnos o remedio proporcionado procurando o quanto nos for possivel o melhor e mais seguro caminho para a salvação de nossos subditos"

Isso comprova que apenas a ação pastoral dos clérigos, as prédicas e as exortações aos bons costumes, não eram suficientes para conter os desvios comportamentais das populações católicas do passado.

Desta maneira, justifica-se que a Igreja, especialmente após o Concílio Tridentino, buscasse consolidar os instrumentos mais eficazes para fiscalizar a população católica que vivia nos diferentes territórios, através da ampliação da autoridade episcopal e da insistência na visita como meio preferencial de exercício da jurisdição. Paralelamente, houve todo um esforço para reformular os meios coercitivos da Igreja perante o descrédito generalizado das censuras espirituais, propondo o uso crescente de punições "temporais", (Carvalho, 1988, p.135).

Compreende-se o cumprimento, à risca, da obrigatoriedade das visitas pastorais nos territórios do arcebispado de Braga, visando a confirmação dos bons costumes e a administração dos oportunos remédios àqueles que os necessitassem, como expressou o arcelispo de Braga $D$. Rodrigo de Moura Teles, na pastoral transcrita pelo pároco de Ronfe.

As freguesias que integravam o Arcebispado de Braga, entre elas, aquela de São Tiago de Ronfe, eram então, periodicamente visitadas por uma comitiva de clérigos que tinha como missão zelar pelo cumprimento das disposições da Igreja Católica e, em especial, as constantes nas constituições do arcebispado.

A regulamentação das visitas pastorais foi tratada por alguns autores, como Soares (1997), mas o artigo publicado em 1993 por Paiva constitui uma coletânea dos diversos textos que normalizaram as visitas em Portugal, com um apêndice documental de interesse sobre as instruções para os visitadores do bispado de Coimbra (Paiva, 1993b).

A processologia visitacional foi detalhadamente descrita por Carvalho e Soares. De maneira geral, havia uma comitiva de seis ou sete pessoas no máximo, com amplos poderes, que durante semanas ou meses se dedicaria à tarefa de examinar e reformar as igrejas e os povos. Esta ia para um mundo dominantemente rural e totalmente católico, ao menos no direito. $O$ centro de interesse era a igreja paroquial e o anúncio da visita enviado alguns dias antes ao pároco, que deveria publicar aos fregueses, por ocasião da missa conventual do primeiro domingo ou dia santo imediato. Este cuidado tentava evitar o não comparecimento dos fregueses (Soares, 1981).

$O$ visitador tinha que supervisionar um conjunto grande de itens, desde os caminhos e as pontes de acesso à igreja, o estado de conservação do templo, da torre e dos sinos, pia batismal, imagens, relíquias, etc. Terminada esta primeira fase, anotava num caderno o que era preciso corrigir e ordenar, para depois escrever no livro dos capítulos de visita. Seguia-se, então, a devassa propriamente dita, de onde vinham à luz as denúncias aos comportamentos que colidiam com as prescrições da doutrina católica.

Ainda de acordo com Soares, se a paróquia ultrapassasse os quarenta fogos, o escrivão lia ao povo congregado o edital ou mandado da visitação, podendo condenar os não-cumpridores e devendo urgir o capitulado. Entretanto, examinava os livros do arquivo paroquial tendo o cuidado de lhe apor o visto com as advertências mais oportunas. Examinava o rol dos confessados, donde escolhia um número suficiente de testemunhas que denunciassem os abusos para tirar devassa à freguesia.

Os próprios párocos, após informar ao visitador os pecados públicos e escandalosos sabidos, recolhiam-se às suas casas até o final da visita. Posto todo o povo fora da igreja e o mordomo à porta, as pessoas vinham denunciar e testemunhar perante o visitador (Soares, idem).

Carvalho e Paiva (1989b) destacam exatamente esta peculiaridade da visita portuguesa, que permitia como fonte de informação não o clero local ou os "notáveis" da paróquia, mas sim todo e qualquer paroquiano, sem aparente discriminąção de condição social. e destacam o manancial de informações fornecidos pelas "devassas" sobre a vida das pessoas, dados importantes em trabalhos de reconstituição de comunidades.

Toda a sorte de abusos e crimes podiam ser 


\section{Ana Silvia Volpi Scott}

denunciados, somando uma lista grande, em que se destacam: judaísmo, reformismo e bigamia, adultério, incesto, amancebamento, lenocínio e outras desonestidades; sacrilégios, superstições e feitiçarias, ódios, usuras, tabulagem, abuso do vinho e das danças lascivas, trabalhos servis nos dias de preceito ou falta à missa nos mesmos, não se confessar ou não se sacramentar em perigo de morte, viverem separados os cônjuges, serões, espadelas ou fiadas, perjúrio etc.(Paiva, 1989) ${ }^{8}$.

Pode-se concluir que os abusos e crimes encontrados para as outras freguesias do Arcebispado de Braga e da Diocese de Coimbra, eram aqueles que também atingiam os fregueses da paróquia de São Tiago de Ronfe.

Sobressairiam os delitos ligados à moral, provenientes dos ajuntamentos entre homens e mulheres, alguma bebedeira e superstições, sendo a referência concludente a este respeito o trecho do inquérito paroquial de 1842 .

"não sendo contudo tão innocentes, que não tenhão participado da desmoralização geral; os seus vicios mais dominantes são os tractos e conversações libidinosas, alguas embriaguezes, e frequientes ratonices"

Se por um lado, não sobreviveram os livros das devassas, é possível uma aproximação consistente a estes abusos, crimes e aos indivíduos que os cometiam, através do citado Roteiro dos Culpados.

O Roteiro dos Culpados da Visita da Terceira Parte de Vermoim e Faria, reúne informações de cerca de um século. Na conclusão da devassa, quando finalmente o visitador sentenciava os culpados era aplicada a cada um a pena e a multa correspondente ao seu delito, esta última atenuada pela pobreza ou por uma penitência espiritual; multas e penas iam-se agravando de acordo com a reincidência e variava desde a culpa em aberto e o termo de fama cessanda até ao livramento como seguro (Soares, 1981).

Contabilizando as visitas por décadas, nota-se

\footnotetext{
${ }^{8} \mathrm{O}$ artigo compara os mecanismos da Inquisição e Visitas Pastorais quanto aos pecados e desvios, mostrando uma divisão de esferas e de competências dos mecanismos de controle. Judaísmo e práticas heréticas transitavam para o Santo Ofício; comportamentos morais desviados, gravitavam na órbita da visita pastoral.
}

um decréscimo das mesmas ao longo dos quase cem anos cobertos pela documentação, característica notada para o caso de diocese de Coimbra (Carvalho \& Paiva, 1989b).

Foram realizadas, nas cinco primeiras décadas, 23 visitas pastorais a São Tiago de Ronfe, entre 1730 e 1777 , contra 17 entre 1780 e 1825 , sendo que, nas primeiras décadas do século XIX acentuou-se o declínio da prática visitacional, com três visitas na década de 1800 , três na de 1810 , e apenas uma na década de 1820.

Tabela 1: Número de Sentenças por Décadas

\begin{tabular}{ll} 
Décadas & Número de sentenças \\
1730 & 101 \\
1740 & 69 \\
1750 & 117 \\
1760 & 128 \\
1770 & 41 \\
1780 & 54 \\
1790 & 30 \\
1800 & 19 \\
1810 & 20 \\
1820 & 4 \\
Total & $\mathbf{5 8 3}$ \\
\multicolumn{2}{c}{ Fonte: Roteiro de Culpados. }
\end{tabular}

Também é testemunho do declínio da prática visitacional, ou pelo menos do seu poder entre a população, o decréscimo no número de denunciados. É flagrante que nas cinco primeiras décadas as visitas além de mais numerosas e regulares (praticamente uma a cada dois anos) havia muito mais setenciados.

Entre 1730 e 1770, 456 fregueses da paróquia de São Tiago de Ronfe foram denunciados nas 23 visitas; são cerca de 20 sentenciados por visita (19.8) e mais de $78 \%$ dos denunciados de todo o período, entre 1730 e 1825 .

De 1780 e 1820 aconteceram 17 visitas e apenas 127 fregueses foram arrolados, dando uma média de 7.5 por visita.

A pergunta que se coloca é: o número de denunciados diminuiu devido à pressão da Igreja e consequiente emenda dos culpados, ou foi reflexo de um crescente abandono da delação por parte dos paroquianos? Parece que a segunda hipótese é a mais 
correta, pois como se verá adiante, a reincidência dos delatados pode indicar um aparente descaso em relação às denúncias.

As décadas que medeiam o século XVIII (1750 e 1760 respectivamente), apresentam-se como aquelas em que os visitadores aplicaram com maior rigor o poder neles investido pelo arcebispo de Braga, e extrapolaram, os indicadores médios de denunciados, embora o número girasse em torno de 20 por visita, na década de 1750 observa-se uma subida para 23.4 e na seguinte ultrapassa 25 fregueses denunciados por visita (25.6).

$O$ ano de 1760 atinge 46 denunciados em uma única visita, mais de $7 \%$ da população maior de confissão, tendo o pároco contabilizado, no rol da desobriga daquele ano, 645 almas.

Da mesma forma, os anos de 1751 e 1767 foram os de maior repressão da Igreja, e de visitadores mais duros no cumprimento das constituições (Carvalho \& Paiva, 1989b). Naquele período, a população de Ronfe presenciou, respectivamente, a condenação de 39 e 38 denunciados, números que extrapolavam o visto até então.

De qualquer modo, a contabilização dos denunciados em cada ano, mostra que houve uma tendência de aumento do poder coercitivo dos visitadores entre as décadas de 1750 e 1760 , seguida de uma queda sensível, que se agudiza no inicio do século XIX.

Mas quais eram as denúncias que mais atingiam a população de São Tiago de Ronfe? Que tipo de desvios predominavam? A lista é longa.

Os abusos e crimes denunciados podem ser agrupados basicamente em duas grandes classes: os relativos à doutrina e aos ensinamentos da religião católica e os relacionados à moral e ao comportamento sexual.

No primeiro grupo estariam incluídos aqueles que faltavam à missa, trabalhavam nos dias santos, praticavam o perjúrio, o ódio, o desrespeito aos pais, desconheciam a doutrina da Igreja, as benzedeiras, a má língua, os tunantes.

O segundo contemplaria todos os comportamentos morais que se desviavam das regras estabelecidas pela Igreja no tocante ao relacionamento entre os sexos: os que praticavam o concubinato, bigamia, adultério, a má vida, as mulheres acusadas de serem devassas, desonestas ou parideiras, os ca- sais que não faziam vida em comum, brigas entre casais, a alcoviteirice, etc.

Nem sempre a fonte utilizada especifica claramente o tipo de desvio, crime cometido, ou supostamente cometido, pelos acusados. É a partir da década de 1740 que aparece com maior consistência o delito de que os indivíduos eram acusados, e definidos também aqueles que direta ou indiretamente participaram do ato, começando a especificar os cúmplices e os consentidores.

Dos 583 denunciados, conhece-se o delito de $472(81 \%)$. Portanto, uma parte significativa dos fregueses de São Tiago de Ronfe tiveram que ajustar as contas com a Igreja, estando envolvida em comportamentos que se desviavam da regra imposta pela religião católica no que se referia ao universo das relações entre homem e mulher. Esta é uma prova indiscutível, de que o cruzamento das informações com a base de dados geral sobre todos os indivíduos que viveram em Ronfe no mesmo período, de um instrumento privilegiado de análise para compreender as formas correntes de envolvimento amoroso e sexual da população daquela comunidade.

Excetuando-se os delitos relativos às faltas com relação à doutrina católica (trabalhar em dias santos, faltar à missa, desobediência aos pais) ficase restrito aos comportamentos ligados a moral sexual. E, nestes termos, dos 472 denunciados para os quais se conhece o delito, em mais de $90 \%$ dos casos (426), seus crimes envolviam algum tipo de relacionamento indesejável ou reprovável entre homem e mulher.

Tabela 2: Tipologia dos Delitos

\section{Cód. Delito}

0 Não declarado*

1 Alcoviteiro(a)

2 Andar de noite

3 Bêbado

4 Benzedeira e Língua

5 Brava

6 Comunicar com esposo(a)

7 Concubinato

8 Consentidor(a)

9 Cúmplice em concubinato

10 Dat má vida à mulher

11 Desobediência aos pais/Tratar mal os pais 


\section{Ana Silvia Volpi Scott}

\begin{tabular}{ll}
12 & Desonesta \\
13 & Devassa \\
14 & Enganar \\
15 & Escandalosa \\
16 & Esfolhada \\
17 & Estar separado(a) do marido/mulher \\
18 & Faltar à missa/Doutrina/não ouvir missa \\
19 & Fazer Fiado \\
20 & Incesto \\
21 & Infamada e separada \\
22 & Lasciva e desonesta \\
23 & Língua \\
24 & Má procedência \\
25 & Má vida \\
26 & Ódio \\
27 & Parideira \\
28 & Perjúrio \\
29 & Perseguir marido e obrigar viver separado \\
30 & Por concorrer (em algum delito) \\
31 & Trabalhar em dias santos \\
32 & Tunante \\
33 & Cúmplice em Incesto \\
34 & Cúmplice em outro delito \\
& Fonte: Roteiro de Culpados. \\
& Boa parte destes não declarados está concentrada na década \\
\hline 130 dando não havia a referência sistemática ao delito.
\end{tabular}

O concubinato era o flagelo que mais atormentava e, ao mesmo tempo, desafiava a igreja e seus visitadores. Das 419 denúncias contabilizadas, 325 envolviam pessoas concubinadas e seus cúmplices, os praticantes de incesto e seus cúmplices, e dois casos de infiamento (coabitação dos esposos antes do casamento), somando $77.6 \%$ das denúncias.

Conhecendo os tipos mais comuns de crimes cometidos pela população da freguesia de Ronfe, imediatamente surge a questão. Quais pessoas estavam envolvidas nas denúncias efetuadas aos visitadores?

O total global dos condenados atinge, como mencionado anteriormente, 583 indivíduos. Não houve uma supremacia de um sexo sobre o outro, permaneceram quase que rigorosamente iguais, 283 mulheres para 284 homens. Acrescente-se ao total, 16 indivíduos para os quais não foi possível definir o sexo.
Tabela 3: Tipologia e Freqüência de Delitos Morais

$\begin{array}{ll}\text { Delito } & \text { Total } \\ \text { 01- Alcoviteiro } & 2 \\ \text { 06- Comunicar com esposo(a) } & 2 \\ \text { 07- Concubinato } & 154 \\ \text { 08- Consentidor(a) } & 10 \\ \text { 09-Cúmplice em Concubinato } & 143 \\ \text { 10- Dar má vida à mulher } & 5 \\ \text { 12- Desonesta } & 19 \\ \text { 13- Devassa } & 14 \\ \text { 14-Enganar } & 1 \\ \text { 15- Escandalosa } & 1 \\ \text { 16-Esfolhada } & 2 \\ \text { 17-Estar separado(a) mulher/marido } & 12 \\ \text { 20- Incesto } & 15 \\ \text { 21- Infamada e separada } & 1 \\ \text { 22- Lasciva e desonesta } & 1 \\ \text { 24- Má procedência } & 1 \\ \text { 25- Má vida } & 1 \\ \text { 27- Parideira } & 1 \\ \text { 29- Perseguir marido... } & 1 \\ \text { 30- Por concorrer ... } & 2 \\ \text { 33- Cúmplice em Incesto } & 11 \\ \text { Total Geral } & 419\end{array}$

Fonte: Roteiro de Culpados.

O estado matrimonial, por outro lado, apresentou grande desequilíbrio; nos 491 indivíduos com estado matrimonial conhecido, predominaram amplamente os solteiros, seguido dos casados e finalmente os viúvos.

Tabela 4: Sentenças por Estado Matrimonial ${ }^{9}$

\begin{tabular}{ll} 
Estado Matrimonial & Total \\
Indeterminados & 30 \\
Não Declarados & 62 \\
Casados & 122 \\
Solteiros & 322 \\
Viúvos & 47 \\
Total Geral & $\mathbf{5 8 3}$ \\
\multicolumn{1}{c}{ Fonte: Roteiro de Culpados. }
\end{tabular}

O quadro altera-se quando as duas variáveis (sexo e estado matrimonial) são consideradas.

- Do total de casos, 92 indivíduos não tiveram seu estado matrimonial definido, em 30 houve impossibilidade de leitura e, em 62 essa informação não existia. 
Tabela 5: Sentenças por Sexo e Estado Matrimonial

$\begin{array}{llll}\text { Estado Matrimonial } & \text { F } & \text { M } & \text { Total } \\ \text { Indeterminados } & 3 & 11 & 14 \\ \text { Casados } & 28 & 94 & 122 \\ \text { Não Declarados } & 24 & 38 & 62 \\ \text { Solteiros } & 213 & 109 & 322 \\ \text { Viúvos } & 15 & 32 & 47 \\ \text { Total Geral } & \mathbf{2 8 3} & \mathbf{2 8 4} & \mathbf{5 6 7}\end{array}$

Fonte: Roteiro de Culpados.

Para os de sexo e estado matrimonial conhecido, houve o predomínio das mulheres solteiras $(37.6 \%)$, seguido pelos homens solteiros $(19.2 \%)$, casados (16.6\%). Viúvos do sexo masculino constituíram $5.7 \%$ dos denunciados, vindo depois as mulheres casadas $(4.9 \%)$, e finalmente as viúvas $(2.6 \%)$.

Deve-se levar em conta, por outro lado, que a reincidência era bastante comum. Uma contabilização grosseira, que inclui apenas aqueles que foram identificados, demonstra que muitos indivíduos eram sistematicamente denunciados, não só ao longo dos anos, mas até numa mesma visita por mais de um delito. Alguns reincidiam uma, duas, três, quatro, cinco e até seis vezes. Nesta situação, encontrou-se Antônio Silva Rebelo, solteiro, Francisco Azevedo, casado, e Leocádia, solteira, envolvidos seguidas vezes nas redes de denúncias aos visitadores, por concubinato, com a agravante de ser incestuoso.

Confrontando o concubinato e o casamento, $o$ avesso e o direito, verifica-se que o perfil dos transgressores não pode estar desvinculado do quadro populacional mais amplo da comunidade entre 1730 e 1825. Só tendo esta perspectiva é que se pode avaliar o significado dos números e porque determinados indivíduos foram envolvidos em situações escandalosas, que desafiavam a moral católica e pública que, em tese, deveria reinar na comunidade.

Tabela 6: Indicadores Gerais da População (1740 - 1825)

\begin{tabular}{|c|c|c|c|c|c|c|c|c|c|c|c|c|}
\hline \multirow[b]{2}{*}{ Ano } & \multicolumn{3}{|c|}{ População Efetiva } & \multicolumn{5}{|c|}{ População Ausente } & \multirow{2}{*}{$\begin{array}{c}\text { População } \\
\text { Total }\end{array}$} & \multirow{2}{*}{\begin{tabular}{|c|} 
Razão de \\
Masculinidade
\end{tabular}} & \multirow{2}{*}{$\begin{array}{c}\text { Totai } \\
\text { de Fogos }\end{array}$} & \multirow{2}{*}{$\begin{array}{c}\text { N" méd. de } \\
\text { pessoas }>7 \\
\text { aros por fogo }\end{array}$} \\
\hline & Fem. & Masc. & Efetiv & Fem. & Masc. & $\begin{array}{c}\% \\
\text { Fem. }\end{array}$ & $\begin{array}{c}\% \\
\text { Masc. }\end{array}$ & $\begin{array}{c}\text { Ausen- } \\
\text { tes }\end{array}$ & & & & \\
\hline 1740 & 318 & 212 & 530 & 24 & 61 & 28,2 & 71,8 & 85 & 615 & 66,7 & 166 & 3,2 \\
\hline 1745 & 367 & 252 & 619 & 28 & 67 & 29,5 & 70,5 & 95 & 714 & 68,7 & 203 & 3,0 \\
\hline 1750 & 350 & 252 & 602 & 27 & 51 & 34,6 & 65,4 & 78 & 680 & 72,0 & 203 & 3,0 \\
\hline 1755 & 337 & 255 & 592 & 17 & 38 & 30,9 & 69,1 & 55 & 647 & 75,7 & 193 & $3, i$ \\
\hline 1760 & 372 & 273 & 645 & 16 & 32 & 33,3 & 66,7 & 48 . & 693 & 73,4 & 211 & 3,1 \\
\hline 1765 & 366 & 263 & 630 & 10 & 53 & 15,9 & 84,1 & 63 & 693 & 71,9 & 210 & 3,0 \\
\hline 1770 & 381 & 274 & 659 & 15 & 56 & 21,1 & 78,9 & 71 & 730 & 71,9 & 226 & 2,9 \\
\hline 1775 & 392 & 283 & 675 & 19 & 54 & 26,0 & 74,0 & 73 & 748 & 72,2 & 230 & 2,9 \\
\hline 1780 & 400 & 285 & 685 & 24 & 64 & 27,3 & 72,7 & 88 & 773 & 71,3 & 220 & 3,1 \\
\hline 1785 & 368 & $26 !$ & 630 & 33 & 49 & 40,2 & 59,8 & 82 & 712 & 70,9 & 210 & 3,0 \\
\hline 1790 & 395 & 302 & 700 & 39 & 46 & 45,9 & 54,1 & 85 & 785 & 76,5 & 239 & 2,9 \\
\hline 1795 & 396 & 325 & 724 & 24 & 44 & 34,8 & 63,8 & 69 & 793 & 82,1 & 237 & 3,1 \\
\hline 1800 & 413 & 316 & 730 & 38 & 58 & 39,6 & 60,4 & 96 & 826 & 76,5 & 239 & 3,1 \\
\hline 1805 & 417 & 330 & 748 & 47 & 35 & 57,3 & 42,7 & 82 & 830 & 79,1 & 230 & 3,3 \\
\hline 1810 & 434 & 319 & 753 & 52 & 57 & 47,7 & 52,3 & 109 & 862 & 73,5 & 239 & 3,2 \\
\hline 1815 & 427 & 302 & 731 & 60 & 68 & 46,9 & 53,1 & 128 & 859 & 70,7 & 235 & 3,1 \\
\hline 1820 & 427 & 302 & 729 & 64 & 74 & 46,4 & 53,6 & 138 & 867 & 70,7 & 232 & 3,1 \\
\hline 1825 & 452 & 336 & 788 & 59 & 64 & 48,0 & 52,0 & 123 & 911 & 74,3 & 243 & 3,2 \\
\hline
\end{tabular}

Fonte: Róis de Confessados.

"Quando a somatória dos efetivos individuais masculinos e femininos não corresponder ao total, a diferença deve-se aos individuos que naqueles anos não tiveram seu sexo determinado devido $d$ ilegibilidade da fonte.

O fio condutor da análise deve repousar sobre alguns dados quantitativos fundamentais. Primeiro, o tamanho da população maior de sete anos entre 1730 e 1825, apanhada pelos róis da desobriga. Neste caso a lacuna dos menores não será relevante, pois não eram alvo das visitas. Só os adultos é que poderiam ter contas a ajustar.
A população cresceu nos quase cem anos, embora se registrasse sempre um contingente significativo de ausentes. Exatamente por isso, ela foi subdividida em dois grandes grupos: a efetiva (de fato presente e residindo na freguesia naqueles anos) e a ausente (embora registrada no rol não residia naquele momento na paróquia). 


\section{Ana Silvia Volpi Scott}

A atenção será concentrada na população efetiva, porque somente os indivíduos presentes poderiam ser alvo de denúncias por parte de seus vizinhos. Inicia-se com um total de 530 pessoas, chegando ao final do período com 788 almas, que se distribuíam por 166 fogos em 1740 e 243 em 1825 (em média 3.2 indivíduos maiores de sete anos, por fogo, nas duas datas limite).

O peso dos ausentes variou muito no decorrer do período, de $7 \%$ (1760) a $16 \%$ em 1820 . Embora a maioria da população ausente fosse do sexo masculino, com picos em 1765 (84\% do total), registraram-se anos significativos para a saída, de ambos os sexos, com a supremacia do feminino na proporção de $57 \%$ de mulheres contra $43 \%$ de homens, para o ano de 1805.

Outro dado contundente é a razão de masculinidade, totalmente distorcida durante 0

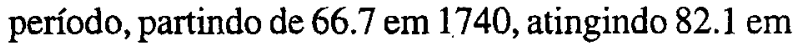
1795 e finalizando com $74.3 \mathrm{em} 1825$. As mulheres constituíam a maioria da população.

Outros indicadores também importantes para analisar o concubinato e o casamento provêm dos registros paroquiais. Foram batizadas 2269 crianças entre as décadas de 1730 e 1820 , sendo 264 de filhos naturais ${ }^{15}$. Finalmente, realizaram-se 460 casamentos na igreja paroquial, e foram sepultados 846 indivíduos, assim distribuídos:

Tabela 7: Movimento de Batizados, Casamentos e Óbitos.

\begin{tabular}{c|c|c|c|c|c}
\hline Período & $\begin{array}{c}\text { Total de } \\
\text { Batiza- } \\
\text { dos }\end{array}$ & $\begin{array}{c}\text { Batizados } \\
\text { llegítimos }\end{array}$ & $\begin{array}{c}\text { \% de } \\
\text { Ilegíti- } \\
\text { mos }\end{array}$ & $\begin{array}{c}\text { Casa- } \\
\text { mentos }\end{array}$ & Obitos \\
\hline $\mathbf{1 7 3 0}-\mathbf{1 7 3 9}$ & 189 & 34 & 18,0 & 33 & 44 \\
\hline $\mathbf{1 7 4 0}-\mathbf{1 7 4 9}$ & 196 & 13 & 6,6 & 48 & 114 \\
\hline $\mathbf{1 7 5 0}-\mathbf{1 7 5 9}$ & 198 & 28 & 14,1 & 51 & 89 \\
\hline $\mathbf{1 7 6 0}-\mathbf{1 7 6 9}$ & 231 & 28 & 12,1 & 64 & 100 \\
\hline $\mathbf{1 7 7 0}-\mathbf{1 7 7 9}$ & 183 & 20 & 10,9 & 29 & 107 \\
\hline $\mathbf{1 7 8 0}-\mathbf{1 7 8 9}$ & 212 & 27 & 12,7 & 52 & 98 \\
\hline $\mathbf{1 7 9 0}-\mathbf{1 7 9 9}$ & 302 & 32 & 10,6 & 59 & 78 \\
\hline $\mathbf{1 8 0 0} \cdot \mathbf{1 8 0 9}$ & 257 & 20 & 7,8 & 44 & 63 \\
\hline $\mathbf{1 8 1 0}-\mathbf{1 8 1 9}$ & 225 & 27 & 12,0 & 43 & 92 \\
\hline $\mathbf{1 8 2 0} \cdot \mathbf{1 8 2 9}$ & 276 & 35 & 12,7 & 37 & 61 \\
\hline
\end{tabular}

Fonte: Registros Paroquiais

A partir da análise das fichas de família, podese chegar a outros dados vitais para contextualizá-la: as idades médias quando do primeiro casamento e o

${ }^{15}$ Não se contempla uma separação entre ilegítimos e expostos, porque esta categoria é inexistente no período. celibato definitivo, tanto para homens como para mulheres.

Tabela 8: Idades Médias ao Primeiro Casamento por Décadas

\begin{tabular}{c|c|c}
\hline Décadas & Sexo Masculino & Sexo Feminino \\
\hline $\mathbf{1 7 3 0}$ & 26.5 & 27.6 \\
\hline $\mathbf{1 7 4 0}$ & 24.3 & 24.8 \\
\hline $\mathbf{1 7 5 0}$ & 28.6 & 28.0 \\
\hline $\mathbf{1 7 6 0}$ & 30.8 & 27.5 \\
\hline $\mathbf{1 7 7 0}$ & 29.3 & 26.7 \\
\hline $\mathbf{1 7 8 0}$ & 28.3 & 24.8 \\
\hline $\mathbf{1 7 9 0}$ & 27.7 & 26.5 \\
\hline $\mathbf{1 8 0 0}$ & 29.2 & 29.3 \\
\hline $\mathbf{1 8 1 0}$ & 30.1 & 27.7 \\
\hline $\mathbf{1 8 2 0}$ & 26.4 & 29.4 \\
\hline Fonte: Fichas de Família. &
\end{tabular}

A par da flagrante evidência da prática de casamentos tardios (sempre acima dos 24 anos para ambos os sexos), a análise destes dados aponta para um outro elemento, que é a inconstância dos indicadores, sem que se defina uma tendência. Ora o casamento realizava-se cedo, ora mais tarde. Ora os homens apresentam idades médias mais elevadas, ora as mulheres. Isso, sem dúvida, é reflexo da exigüidade da amostra, que se acentua de forma proporcional à redução do período escolhido.

Contudo, esta é uma opção deliberada, e interessa estabelecer relações entre a ação pastoral da igreja através das visitas e o comportamento da população diante das admoestações e condenações colocadas em prática.

O celibato definitivo é outro aspecto a ser considerado.Entretanto, sua análise ficaria comprometida optando-se por manter a divisão em períodos decenais, já que são poucos os casos de identificação positiva do indivíduo no óbito, para os quais se conhece o estado matrimonial e a idade. Assim, apenas como indicador de grandezas, decidiuse por dividir em dois períodos: entre 1730 e 1779 (maior incidência das visitas) e 1780 e 1829 (declínio prática visitacional). 
Tabela 9: Celibato Definitivo por Período

\begin{tabular}{l|c|c|c|c|c|c}
\hline & \multicolumn{3}{|c|}{ Masculino } & \multicolumn{3}{c}{ Feminino } \\
\hline & Tot. 6 bit. & Obit 50+solt & Celibato def & Tot. Obit. & Obit 50+solt & Celibato def \\
\hline $\mathbf{1 7 3 0 - 1 7 7 9}$ & 47 & 9 & 19.1 & 86 & 367 & 45.4 \\
\hline $\mathbf{1 7 8 0 - 1 8 2 9}$ & 94 & 10 & 10.6 & 114 & 28 & 24.6 \\
\hline Fonte: Fichas de Família
\end{tabular}

Portanto, pode-se concluir que o quadro populacional e demográfico da comunidade de São Tiago de Ronfe apresentava uma população em constante crescimento, embora houvesse sérios desequilíbrios na proporção dos sexos, com uma supremacia feminina significativa e constante.

Certamente este quadro foi responsável por oportunidades diferenciadas de acesso ao matrimônio, lançando para patamares elevados as idades médias no primeiro casamento e os índices de celibato da população em geral, com ênfase especial para o feminino.

Neste mesmo contexto, tem-se que enquadrar os índices de ilegitimidade significativos encontrados, que partiram de $18 \%$ na década de 1730 e apresentaram uma tendência de queda até o final do período, atingindo pouco mais de $12.5 \%$.

Alguns indícios recolhidos apontam para o fato de que esta comunidade era composta por categorias muito diferenciadas social e economicamente, como se depreende do esboço de classificação elaborado pelo pároco da freguesia em meados do século XIX, que dividiu a população em categorias que iam desde os "proprietários de bens" (a minoria) até aos "caseiros de eido ou cabana" (maioria). Em 1842 eram 19 proprietánios de bens, 48 proprietários de eido ou cabana, 27 caseiros de bens e 122 caseiros de eido ou cabana ${ }^{16}$.

$\mathrm{O}$ quadro geral desta freguesia mostrou uma situação de desequilíbrios em diversos níveis: minoria de proprietários, super-população feminina, e acesso restrito e tardio ao casamento; acrescente-se um contingente significativo de fogos chefiados por mulheres sós. Estes são ingredientes que permitem refletir sobre o quotidiano, especialmente do reservado às mulheres.

Parece lícito aceitar que a imagem desenhada para as mulheres do Alto Minho se encaixe na situação das de Ronfe.

${ }^{16}$ Fonte: Inquérito Paroquial de 1842, depositado na Biblioteca da Sociedade Martins Sarmento (Guimaräes). "as mulheres que não possuiam nenhuma terra estavam numa posição menos desejável (...), pois elas não só ficavam solteiras, como não tinham a segurança da pertença a uma casa agrícola, uma vez que na maior parte dos casos se tratava já de filhas de mães solteiras. Era freqüente viverem em condições precárias, em antigos estábulos ou casebres arrendados aos lavradores ricos em cujas terras trabalhavam. O seu emprego, no entanto, era irregular pois eram pagas ao dia (a jornal)"

Uma situação precária, sem dúvida, que poderia levar a encarar a maternidade ilegítima como tábua de salvação, já que para muitas mulheres pobres seus filhos sempre tinham um enorme valor, na medida em que seu trabalho seria precioso (O'Neill, 1985b, p.141) e mais ainda, que estes seriam considerados como um potencial e quase único amparo na velhice. Nesta perspectiva, parece lógico concluir que "é melhor um filho bastardo que nenhum" (O'Neill, 1985b).

Admitindo-se que o desequilíbrio entre os sexos afetava as chances de acesso ao casamento para boa parte das mulheres (comprovado pelo elevado número de celibato definitivo encontrado) $\mathrm{e}$ mais ainda, que essa comunidade tinha profundas diferenças de estatuto social e econômico, compreende-se que, para uma parcela importante desta sociedade, não havia alternativa, a não ser a transgressão, como oportunidade final de ter uma prole, ainda que bastarda, que assegurasse sua sobrevivência futura.

Não surpreende, pois, que apesar da vigilância e do controle que a igreja procurava manter sobre seu rebanho, através da ação concreta dos seus delegados (os visitadores), o número denunciado de casos de concubinato correspondesse à maioria dos delitos arrolados. 


\section{Ana Silvia Volpi Scott}

Tabela 10: Distribuição das Sentenças X Tipo de Delito

\begin{tabular}{c|c|c|c|c|c|c|c|c}
\hline Período & $\begin{array}{c}\text { Não } \\
\text { Declarado }\end{array}$ & $\begin{array}{c}\text { \%ão Declar./ } \\
\text { Total }\end{array}$ & Morais & $\begin{array}{c}\text { Concub. } \\
\text { ou } \\
\text { Cúmplices }\end{array}$ & $\begin{array}{c}\text { \% } \\
\text { Concub./ } \\
\text { Morais }\end{array}$ & $\begin{array}{c}\% \\
\text { Concub./ } \\
\text { Total }\end{array}$ & Outros & $\begin{array}{c}\text { Total de } \\
\text { Sentenças }\end{array}$ \\
\hline $1730-1739$ & 76 & 75,2 & 18 & 10 & 55,6 & 9,9 & 7 & 101 \\
\hline $1740-1749$ & 8 & 11,6 & 46 & 40 & 87,0 & 58,0 & 15 & 69 \\
\hline $1750-1759$ & 2 & 1,7 & 93 & 82 & 88,2 & 70,1 & 22 & 117 \\
\hline $1760-1769$ & 5 & 3,9 & 103 & 87 & 84,5 & 68,0 & 20 & 128 \\
\hline $1770-1779$ & 0 & 0,0 & 26 & 26 & 100,0 & 63,4 & 15 & 41 \\
\hline $1780-1789$ & 3 & 5,6 & 44 & 36 & 81,8 & 66,7 & 7 & 54 \\
\hline $1790-1799$ & 16 & 53,3 & 11 & 10 & 90,9 & 33,3 & 3 & 30 \\
\hline $1800-1809$ & 1 & 5,3 & 15 & 14 & 93,3 & 73,7 & 3 & 19 \\
\hline $1810-1819$ & 0 & 0,0 & 19 & 14 & 73,7 & 70,0 & 1 & 20 \\
\hline $1820-1829$ & 0 & 0,0 & 4 & 4 & 100,0 & 100,0 & 0 & 4 \\
\hline
\end{tabular}

Fonte: Roteiro de Culpados.

Desconsiderando-se as décadas de 1730, 1790 e $1820^{17}$, vê-se que o concubinato representava quase sempre mais de dois terços das denúncias. Separados apenas os delitos relacionados a desvios de conduta moral, o concubinato assume proporções de mais de $80 \%$ em todo o período, chegando à totalidade dos casos denunciados durante a década de 1770.

A tabela seguinte traz o número de casamentos em relação ao total de indivíduos envolvidos em concubinato ${ }^{18}$.

Tabela 11: Casamentos e Indivíduos Concubinados

\begin{tabular}{c|c|c}
\hline Décadas & $\begin{array}{c}\text { Número de } \\
\text { Casamentos }\end{array}$ & Concubinatos \\
\hline $\mathbf{1 7 3 0}$ & 33 & 10 \\
\hline $\mathbf{1 7 4 0}$ & 48 & 40 \\
\hline $\mathbf{1 7 5 0}$ & 51 & 82 \\
\hline $\mathbf{1 7 6 0}$ & 64 & 87 \\
\hline $\mathbf{1 7 7 0}$ & 29 & 26 \\
\hline $\mathbf{1 7 8 0}$ & 52 & 36 \\
\hline $\mathbf{1 7 9 0}$ & 59 & 10 \\
\hline $\mathbf{1 8 0 0}$ & 44 & 14 \\
\hline $\mathbf{1 8 1 0}$ & 43 & 14 \\
\hline $\mathbf{1 8 2 0}$ & 37 & 4 \\
\hline
\end{tabular}

Fonte: Registros Paroquiais de Casamentos e Roteiro de Culpados.

As décadas de 1750 e 1760 , que apresentaram o maior número de pronunciados envolvidos em concubinato, indicam pressão dos visitadores na perseguição daquele desvio, pois há o dobro de

\footnotetext{
${ }^{17}$ Em 1730 há poucos casos de delitos declarados, em 1820, aparecem apenas 4 pronunciados (todos por concubinato); e na década de 1790 parte da documentação estava ilegível.

${ }_{18}$ Nesta rubrica somam-se todos os denunciados por concubinato, por incesto bem como os seus cúmplices.
}

denúncias da década anterior (1740) e pouco mais de um terço da seguinte (1770). A queda não pode ser atribuída à emenda dos fiéis, em razão da pressão dos visitadores, pois, ao mesmo tempo, caiu também em cerca de $50 \%$ o número de casamentos realizados. Portanto, não fica claro, pelo menos nestes dados, as razões que levaram à mudança de comportamento no período.

Uma perspectiva, até agora deixada de lado por muitos investigadores que estudam a família em Portugal, é a existência da "bastardy prone society". (Laslett, Oosterveen \& Smith, 1980, p. 217).

Cabral (1984) é um dos defensores da idéia de que o campesinato sem terra do Alto Minho aproximar-se-ia deste modelo. Um artigo mais recente, de 1996, indica a possibilidade de existência desse subgrupo com propensão à bastardia, face aos dados de diversos trabalhos que analisaram no Norte de Portugal (Sá, 1996).

Muitos autores encontraram uma incidência de mulheres com mais de uma criança ilegítima, podendo atingir proporções consideráveis no total de mães de filhos naturais. Brettell (1986), por exemplo, encontrou cerca de $50 \%$ de mães solteiras com mais de um filho.

São Tiago de Ronfe apresenta tendência semelhante. Registrou-se um subgrupo de mulheres que é responsável por mais de um nascimento ilegítimo, representando $35 \%$ do total.

A reconstrução da trajetória de vida dessas mulheres é difícil ou pelo menos bastante comprometida, face a sua correta identificação, pois na maioria dos casos nos registros de batismo dos filhos, a mãe era apenas mencionada com o seu nome e quase sempre, sem outros laços de parentesco que 
pudessem enquadrá-la em grupo familiar mais alargado. Isto sem contar com os frequientes casos de homônimos ${ }^{20}$. Felizmente, algumas delas eram tratadas também por alguma alcunha, um poderoso instrumento para dirimir dúvidas quando de sua identificação.

Estas alcunhas, além de facilitarem a identificação, podem ser indicadores de um estigma de sua condição, já que as mães de filhos legítimos não são jamais designadas através delas (Neves, 1996). Alguns exemplos encontrados para as mulheres de Ronfe são interessantes: Ana $a$ Gata, Ana Peixota a Gaiteira, Angela a Torrucha, Catarina a Dura, Catarina $a$ Porra, Isabel a Marquesa, Isabel a Preta, Isabel João a Alheira, Maria Fernandes $a$ Perna, Jeronima a Preziga.

Algumas geraram filhos naturais e foram denunciadas aos vistadores como parideiras, devassas ou desonestas; isto possibilitou, em alguns casos, a identificação do pai da(s) criança(s), não mais referido a partir do início de 1700 , por determinação do Arcebispo de Braga. Por aí, pode-se assumir que muitos dos relacionamentos ilícitos eram estáveis, pois os pares de acusados se repetem.

A pergunta que se coloca é quantos dos indivíduos envolvidos em relações ilícitas e moralmente reprováveis poderiam alterar esta situação?

Talvez a única forma que se tenha para refletir sobre esta hipótese é examinar o estado matrimonial dos indivíduos pronunciados nos casos de concubinato e incesto.

Tabela 12: Estado Matrimonial dos Parceiros Concubinados

\begin{tabular}{l|c|c|c|c}
\hline & \multicolumn{4}{|c}{ Sexo Feminino } \\
\hline Sexo Masculino & Casadas & Solteiras & Viúvas & Total \\
\hline Casados & 2 & 35 & 5 & 42 \\
\hline Solteiros & 1 & 47 & 2 & 50 \\
\hline Viúvos & 0 & 16 & 3 & 19 \\
\hline Total & $\mathbf{3}$ & $\mathbf{9 8}$ & $\mathbf{1 0}$ & $\mathbf{1 1 1}$ \\
\hline Fonte: Roteiro de Culpados.
\end{tabular}

Fonte: Roteiro de Culpados.

\footnotetext{
${ }^{20}$ Neves (1996) apresenta um cálculo que dá a dimensão do problema da identificação de maes solteiras. Trabalhando com a ilegitimidade em freguesias do norte do Conselho de Guimarães, encontrou que para o século XVIII, em mais de $50 \%$ dos casos os nomes das mães de crianças ilegftimas estavam divididos entre Maria (30.1\%), Catarina (11.3\%) e Isabel (9.2).
}

Embora poucas tenham sido as situaçōes em que foi possível identificar seguramente o estado matrimonial do par denunciado, em muitas näo adiantava recorrer à emenda dos pronunciados porque as relações ilícitas reuniam alguns indivíduos já casados.

De 111 situações encontradas em todo o período, em $37.8 \%$ dos casos ( 42 ocorrências) o homem envolvido na relação era casado. Portanto em todas estas modalidades, as mulheres que mantinhám relações com aqueles indivíduos, dificilmente teriam sua condição de concubinas modificada, porque seu parceiro não era livre para desposá-las.

Os viúvos ligavam-se majoritariamente a mulheres solteiras (pouca incidência de viúvas), e nunca ocorreu de um viúvo ter relações publicamente reconhecidas com mulheres casadas. Dos 19 casos ( $17 \%$ da amostra) não havia um impedimento claro para passarem da condição de concubinados para a de marido e mulher.

É relevante,que a porcentagem de pares de indivíduos pronunciados por andarem concubinados, sendo ambos solteiros e, portanto, com chance de deixarem de ser alvo da delação nas visitas pastorais. Havia nestas condições $42.3 \%$ dos casos.

Dada a natureza das fontes utilizadas, não foi possível saber se alguns dos parceiros solteiros apresentavam outros impedimentos para a realização das núpcias ${ }^{2}$. Mas, se alguns estivessem enquadrados nesta situação, outros que não estivessem, não teriam uma razão plausível (do ponto de vista canônico, pelo menos) para a manutenção de um comportamento que era escandaloso diante da comunidade. $O$ fato é que os casos concretos que uniam parceiros solteiros repetiram-se incessantemente, como se pode observar nos exemplos tirados da documentação.

Antônio Silva Rebelo, foi denunciado seguidas vezes. Ele era filho de João Rebelo, proprietário, e de Catarina da Silva, residentes no lugar do Assento. $\mathrm{Na}$ visita do ano 1754, ainda solteiro, foi acusado duas vezes. Primeiro por desobedecer aos pais e depois, por andar concubinado com Maria,

\footnotetext{
${ }^{21}$ A freguesia de Ronfe dispõe de uma coleção de Licenças Matrimoniais. Entretanto o período coberto por esta fonte está restrito ao século XIX, com poucos casos relativos ao XVIII quando as visitas são frequentes e numerosas.
} 
solteira, filha de Domingos Machado. No ano de 1757, Antônio Rebelo, foi novamente envolvido numa denuncia de concubinato, desta vez com Maria Carvalha, solteira, filha de outra Maria Carvalha. $\mathrm{O}$ casal foi novamente denunciado na visita realizada durante $o$ ano de 1760, ambos ainda solteiros, ela residente no lugar do Souto, e ele residente no lugar da Igreja.

Mas, a história de amores ilícitos de Antônio não terminaria por aî. No ano seguinte (1761), foi novamente denunciado e sua cúmplice era outra, a Senhorinha, moradora no mesmo lugar do Assento e filha de Miguel Vieira. Os dois eram solteiros, viviam na freguesia de Ronfe e residiam em fogos contíguos, ela juntamente com seus pais, Miguel Vieira e Jeronima Gonçalves, e sua irmã Rosa, ele com sua mãe viúva, Catarina Silva.

Antônio Silva Rebelo foi condenado a pena foi bastante severa, seguramente devido às seguidas denúncias de que foi alvo e Senhorinha, que jamais havia sido denunciada, acabou por assinar um termo de negação.

A julgar pelos acontecimentos, a pressão exercida pelos visitadores teve um efeito "positivo", pois naquele mesmo ano de 1761 , no dia 12 de outubro, foram recebidos na igreja de Ronfe. Deste casamento, que durou até o ano de 1791, quando faleceu Senhorinha, nasceram sete filhos, dois rapazes e cinco raparigas.

Outros indivíduos também foram seguidamente denurciados, como André Pinheiro. Em 1733 já viúvo, foi acusado de concubinato com Joana Correia, solteira, filha de João Correia. Dois anos mais tarde, repetiu-se a denúncia. No ano de 1741, persistiam na relação ilícita, embora, o caso tenha sido declarado em aberto. Posteriormente verificou-se que o casal teve um filho, através das fichas de famílias ilegítimas constava explicitamente André Pinheiro como pai e Joana Correia como mãe.

O que foi demonstrado é extremamente pertinente e leva a perguntar porque os indivíduos continuavam mantendo relações ilícitas, apesar da constante vigilância e punição imposta pela Igreja aos delinqüentes, através da ação dos visitadores.

Parece muito simples atribuir esses comportamentos à devassidão ou desmoralização dos costumes, como fez o reitor de Ronfe em 1842, salientan- do a pouca inocência de seus fregueses, que se davam "a tratos ilícitos e conversações libidinozas".

Porém, o exame mais cuidadoso de alguns casos, com dados reunidos através do cruzamento de fontes, coloca outros imperativos que constrangeriam os indivíduos a comportamentos condenados pela igreja e sociedade.

Uma história de vida rica em situações complexas, no campo das relações pessoais e familiares, foi a de Bento Oliveira Marques e Jeronima Ribeiro. Ele, filho mais novo de João Oliveira e de Jeronima Francisca, ambos proprietários em Olival, nasceu no dia 12 de dezembro de 1725 . Em 1740 residia com sua mãe, já nesta altura viúva. Compartilhavam o mesmo fogo seus irmãos João, Domingos, Teresa e seu tio, Estevão.

Aos vinte anos, 1745 , continuava sob o teto de sua mãe, em Olival, convivendo com seu irmão Domingos e seu tio. Em 1750 não foi localizado, estando provavelmente ausente da freguesia e sua mãe aparece agregada ao fogo chefiado por Domingos Francisco, casado com Paula Ferreira, com os quais não foi estabelecida qualquer relação de parentesco.

Cinco anos mais tarde, no rol de 1755 , Bento está de volta e sua mãe, em fogo separado está na cabeça do agregado habitado pelos dois.

No ano de 1762, Bento casou-se na igreja de Ronfe e tudo indica que tenha continuado a viver juntamente com sua mãe, até o falecimento dela, assentado no livro de óbitos da freguesia, em março de 1765 .

Até aqui, não se poderia suspeitar de irregularidade, de ordem moral, que pudesse ter denegrido seu comportamento diante da comunidade e lançado o casal nas malhas da justiça episcopal.

Os indícios de uma vida mais atribulada, no nível das relações pessoais e amorosas, surge a partir dos dados recolhidos no rol de 1765 . Bento aparece casado e a chefiar o fogo, com dois filhos, Bento e Manuel. Por conseguinte, estes deveriam ter mais que sete anos, pois de outra forma não figurariam no rol. Fazendo-se as contas, Bento e Jeronima haviam se casado em 1762, ou seja, apenas três anos antes.

De acordo com a ficha de família do casal, eles tiveram só dois filhos, Manuel ( $s i c$ ) do qual não se sabe a data de nascimento, e Domingos, nascido já durante a vigência do casamento de ambos (mar- 
ço de 1764). O filho chamado Bento, arrolado nos róis, nem se quer foi mencionado na ficha de família.

Tudo começa a fazer sentido ao cruzar os seus nomes no Roteiro dos Culpados, atentando para o fato de que, tanto Bento quanto Jeronima, coincidentemente estiveram ausentes da freguesia em $1750 \mathrm{e}$ que na visita pastoral em Ronfe, em 1751, os visitadores ouviram denúncias de que Bento e Jeronima viviam concubinado e que os pais dela, Jeronimo Ribeiro e Ana Barbosa, eram "consentidores" do delito. A história, pois, começa a mostrar o conflito que se instaurou nas suas vidas, por mais de dez anos, entre a primeira denúncia de concubinato e a realização de seu casamento.

Jeronima Ribeiro era a terceira filha de Jeronimo Ribeiro, caseiro do lugar da Vinha Velha, e Ana Barbosa, tendo nascido em 24 de agosto de 1726 e havia mais quatro irmãs, Monica, Joana, Maria e Ana Maria.

No rol de confessados de 1740 , a família de Jeronima residia em Poça. No ano de 1750 , tudo pareceria normal, pois no agregado familiar filha Jeronima havia sido registrada como ausente.

Parece claro, então, que o casal teve que adiar a formalização de sua união por qualquer motivo, já que ambos, em princípio, não teriam qualquer impedimento para se unir, pois eram solteiros e do que consta, sem laço nenhum de parentesco que pudesse impedi-los. Portanto, outro deve ter sido o motivo que os sujeitou a uma situação de vexame público, envolvidos nas denúncias efetuadas por ocasião da visita.

Uma hipótese é a que ligaria o condicionamento da sua união ao acesso à chefia do agregado doméstico e/ou à gestão da propriedade dos pais de Bento. Sua mãe, viúva, não se sabe a partir de quando, pode ter relutado em passar a chefia e autoridade do fogo, e conseqüentemente da propriedade a seu filho. Bento desposou Jeronima, que já havia perdido seus pais em 1755 , apenas poucos anos antes do falecimento de sua mãe. Infelizmente não há como comprovar esta hip6tese, pois os pais de Bento não deixaram testamento.

Também não foi possível relacionar o nome de Jeronima, como mãe de qualquer um dos nascimentos de crianças ilegítimas batizadas em Ronfe. Uma hipótese explicativa seria a de que ela optou por ter as crianças ilegítimas fora da sua freguesia, buscando, quem sabe, o apoio e cumplicidade de suas irmãs, que por diversas ocasiões estiveram ausentes da casa dos pais.

A família de Jeronimo Ribeiro caiu nas malhas dos visitadores mais uma vez. Por ocasião da visita realizada em 1750 , outra filha de Jeronimo Ribeiro e Ana Barbosa, Joana, esteve ligada a um caso de concubinato que envolvia um homem casado, Manuel Silva, de Quintela, cuja mulher era Jeronima Mendes.

Talvez, essa possa ser uma outra hipótese explicativa na demora da realização do casamento entre Bento e Jeronima, na medida em que essa união não seria aceita por sua mãe, que poderia considerar a família da nora inadequada, dado o envolvimento de seus membros nas denúncias aos visitadores, e por pertencerem a um estrato social inferior: uma família de caseiros unindo-se a uma de proprietários. São hipóteses plausíveis, mas não deixam de estar no campo das especulações.

As acusações de concubinato, por fim, não excluíram nem o Reitor de Ronfe, João Couto Ribeiro, que em 1750 foi denunciado por estar concubinado com Custodia, de alcunha $A$ Galega, filha de Catarina Francisca, viúva, de Souto. Entretanto, ambos assinaram um termo de negação, recusando-se a àceitar como verdadeira as acusações a eles imputadas. No seu testamento, redigido em 14 de julho de 1780, João do Couto Ribeiro não mencionou Custodia nem algum eventual filho que pudesse ter sido fruto desta ou de outras relações espúrias aos olhos da Igreja e de seus paroquianos.

Outra pergunta que não se pode deixar de fazer é: todos os indivíduos que praticavam delitos eram denunciados?

Tomando-se por base a documentação referida por Neves (1996), parece que a resposta seria não. Na Lei sobre os Julgadores de Lisboa, de 1608, na parte que tratava das mulheres públicas e da obrigação de levá-las para lugares previamente determinados (as ruas públicas ordenadas pela Lei), havia instruções explícitas para que esse procedimento não fosse aplicado no caso de elas terem " $\mathrm{em} \mathrm{seu}$ viver mais resguardo" e não serem "tão públicas e escandalosas", devendo os julgadores usar de maior tolerância nestas circunstâncias.

Seria possível que isso ocorresse também fora 
das zonas urbanas, nas freguesias rurais? Ou os comportamentos ilícitos seriam denunciados apenas, e tão somente, quando fossem excessivamente escandalosos?

É possível que o tipo de povoamento disperso característico do Minho ajudasse a encobrir relacionamentos que deveriam ser mantidos ocultos e, portanto, longe da esfera pública. Na comarca de Entre Douro e Minho, desde o século XVI, há referência à raridade de povoações juntas e ao fato dos seus moradores viverem "por quintas e casais apartados"(Ribeiro, 1991, p. 318).

Ribeiro (1991) acreditá que esta situação de povoamento disperso proporcionava menor visibilidade que em outras regiões, pois ali as pessoas estavam menos sujeitas aos olhares indiscretos dos vizinhos.

Tudo indica que os indivíduos denunciados nas visitas tinham um comportamento que permitia à comunidade em que viviam, mesmo que dispersa pelas quintas e casas isolados, estar ao corrente de determinadas situações. Isto leva a aceitar a hipótese que só os casos muitos escandalosos seriam levados ao conhecimento dos visitadores, uma vez que a intimidade estaria minimamente assegurada pelo isolamento em que os fregueses se encontravam.

Ainda hoje, um passeio pela freguesia faz sentir o isolamento e a distância que separa as casas. É inevitável conjeturar que, mais de dois séculos antes, esse isolamento fosse muito forte.

Portanto ter o nome citado no Roteiro dos Culpados deveria significar que o comportamento privado dos indivíduos tornava-se de tal forma incômodo e escandaloso a ponto de colidir frontalmente com a moral católica e pública, levando ao conhecimento e à denúncia.

Diante de uma comunidade em que uma parcela significativa da população feminina tinha suas chances de acesso ao casamento legítimo reduzidas, senão mesmo inviabilizadas, seria menos o concubinato em si, e mais o escândalo e publicização de alguns relacionamentos, que despertaria a necessidade da denúncia.

Afinal, numa comunidade de pequenas dimensões, os comportamentos avessos aos preceitos morais e religiosos não eram propriamente estranhos ao quotidiano dos paroquianos e da autoridade moral máxima, representada pelo pároco, que ordinariamente dividiam e conviviam no mesmo espaço. Parece que a questão principal não era estar ou não em conformidade com a regra social e religiosa: $O$ avesso $e$ o direito poderiam coexistir complacentemente, desde que, na ausência do escândalo.

\section{Referências Bibliográficas}

Afonso, B. (1985). Livros de Devassa e Etnotextos. Trabalhos em Antropologia e Etnologia 25 (24):347-358.

Albino, T.J. (1986). Mães solteiras numa aldeia transmontana. Análise Social XXII (92-93):683695.

Amorim, M.N. (1987). Guimaräes de 1580-1819: Estudo Demográfico. Lisboa: Instituto Nacional de Investigações Científicas.

Amorim, M.N.(1995). História da Família em Portugal. Ler História 29:5-17.

Bethencourt, F. (1987). As visitas pastorais. Um estudo de caso (Entradas, 1572-1593). Revista de História Económica e Social XIX.

Boisvert, C.C. (1988). f'illégitimité en question: les enfants naturels et leurs meres d'aprés les registres paroissiaux d'une 'freguesia' de l'Alto Minho. Medidies (7/8).

Brettell, C.B. (1985). Male Migrants and Unwed Mothers: Illegitimacy in a Northwestern Portuguese Town. Anthropology IX (2):87-109.

Brettell, C.B. (1986). Men who migrate, women who wait. Population and History in a Portuguese Parish. Pricenton: Pricenton U. Press.

Brettell, C.B. (1988). Emigration and Household Structure in a Portuguese Parish, 1850-1920. Journal of Family History 13 (1):33-57.

Brettell, C.B. (1991). Homens que partem, mulheres que esperam: consequências da emigração numa freguesia minhota. Lisboa: Publicações Dom Quixote.

Brettell, C.B. \& Metcalf, A.C. (1993). Family customs in Portugal and Brazil: transatlantic parallels. 


\section{Continuity and Change 8 (3):365-388.}

Carvalho, J. \& Paiva, J.P. (1989a). A Diocese de Coimbra no século XVIII. População, Oragos, Padroados e Titulação dos Párocos. Revista de História das Ideias 11:175-269.

Carvalho, J. \& Paiva, J.P. (1989b). A evolução das visitas pastorais da Diocese de Coimbra nos séculos XVII e XVIII. Ler História (15):29-41.

Carvalho, J.R. de. (1985). As Visitas Pastorais e a Sociedade de Antigo Regime. Notas para o estudo de um mecanismo de normalização social. Coimbra: Faculdade de Letras da Universidade de Coimbra.

Carvalho, J.R. de. (1988). A jurisdição episcopal sobre leigos em matéria de pecados públicos: as visitas pastorais e o comportamento moral das populações portuguesas de Antigo Regime. $R e$ vista Portuguesa de História 24:121-163.

Carvalho, J.R. de \& Paiva, J.P.M. (1985). Reportório das visitas pastorais da diocese de Coimbra, nos séculos XVII, XVIII e XIX. Boletim do Arquivo da Universidade de Coimbra VII:111-214.

Chaunu, P. (1986). A civilização da Europa das Luzes. Lisboa: Editorial Estampa.

Flinn, M.W. (1981). The European Demographic System (1500-1820). Suffolk: St. Edmundsbury Press.

Grieco, S.F.M. (1994). O Corpo, aparência e sexualidade. In História das Mulheres. Porto: Afrontamento.

Laslett, P., Oosterveen, K. \& Smith, R. (1980). Bastardy and its Comparative History. London: Edward Arnold.

Lynch, K.A. (1994). The Family and the History of Public Life. The Journal of Interdisciplinary History XXIV (4):665-684.

Neves, A.A.A.A. (1996). Filhos das Ervas. A ilegitimidade no Norte de Guimarães (séculos XVIXVIII). Master, Depto. de História, Universidade do Minho, Braga.

O'Neill, B.J. (1984). Proprietários, Lavradores e Jornaleiras. Desigualdade social numa al- deia transmontana, 1878-1978. Lisboa.

O'Neill, B.J. (1985a). Jornaleiras e Zorros: Dimensões da llegitimidade numa Aldeia Transmontana, 1879-1978. In Les Campagnes Portugaises de 1870 a 1930: Image et Realité. Paris: Fondation Calouste Gulbenkian.

O’Neill, B.J. (1985b). Morrer e Herdar no Trás-osMontes Rural. In A Morte no Portugal Contemporâneo. Aproximações Sociológicas, Literárias e Históricas, Org. R. G. Feijó, H. Martins e J. Pina Cabral. Lisboa: Querco.

O'Neill, B.J. (1987). Social Inequality in a Portuguese Hamlet. Land, late marriage, and bastardy, 1870-1978. Cambridge: Cambridge University Press.

Paiva, J.P. (1991). A administração diocesana e a presença da Igreja. O caso da Diocese de Coimbra nos séculos XVII e XVIII. Lusitânia Sacra $2^{\text {a }}$ Série (3):71-110.

Paiva, J.P. (1993a). O cerimonial da Entrada dos Bispos nas suas Dioceses: Uma Encenação de Poder (1741-1757). Revista de História das Idéias 15:117-146.

Paiva, J.P. (1993b). Uma instrução aos Visitadores do Bispado de Coimbra (Século XVII?) e os Textos Regulamentadores das Visitas Pastorais em Portugal. Revista de História das Idéias 15:637-661.

Paiva, J.P. de M. (1989). Inquisição e visitas pastorais. Dois mecanismos complementares de controle social? Revista de História das Idéias 11:85-102.

Pereira, I. da R. (1965). Os livros de visitas pastorais. Coimbra.

Pereira, I. da R. (1973). As visitas paroquiais como fonte histórica. Uma visitação de 1760. Separata da Revista da Faculdade de Letras da Universidade de Lisboa $3^{a}$ série (15):11-71.

Pereira, I. da R. (1980). Subsídios para a história da diocese de Lisboa no século XVIII. Lisboa: Academia Portuguesa de História.

Pereira, I. da R. (1992). Visitas Paroquiais dos sécu- 
56 Ana Silvia Volpi Scott

los XIV, XV e XVI. Lusitania Sacra $2^{\mathbf{a}}$ série (4):311-344.

Pina Cabral, J. de (1984). As mulheres, a maternidade e a posse da terra no alto Minho. Análise Social 20 (1):97-112.

Pina Cabral, J. de (1989). Filhos de Adão, Filhas de Eva. A visão de mundo camponesa no Alto Minho. Lisboa: Publicações D. Quixote.

Ribeiro, O. (1991). Opúsculos Geográficos. O Mundo Rural. Lisboa: Fundação Calouste Gulbenkian.

Rodrigues, A.C.G. (1985). Subsídios para o estudo da diocese de Coimbra. O Bispo-Conde D. João de Melo (1624-1704). Boletim do Arquivo da Universidade de Coimbra VII:235-351.

Sá, I.G. (1996). Abandono de crianças, ilegitimidade, e concepções pré-nupciais em Portugal: estudos recentes e perspectivas. In Expostos e Ilegítimos na Realidade Ibérica do século XVI ao presente. Actas do III Congresso da ADEH, Org. V. Pérez-Moreda. Porto: Afrontamento.

Santos, E. dos. (1979). Os livros de visitas pastorais da região portuense. Questões e perspectivas de abordagem. Revista de História 2.

Soares, A.F.N. (1997). A Arquidiocese de Braga no século XVII. Sociedade e Mentalidades pelas Visitações Pastorais (1550-1700). Braga.

Soares, F.N. (1972). A arquidiocese de Braga no século XVI - Visitas pastorais e livros de visitações. Tese de Licenciatura, Faculdade de Letras da Universidade do Porto, Universidade do Porto, Porto.

Soares, F.N. (1978). A sociedade de Antigo Regime nas visitações e inquéritos paroquiais do distrito de Braga. Theologica XIII.

Soares, F.N. (1981). Visitações e Inquéritos Paroquiais da Comarca da Torre de Moncorvo de 1775 a 1845. Braga.

Soares, F.N. (1983). Visitações de D. Fr. Baltasar Limpo na Arquidiocese de Braga. Visitações à colegiada de Nossa Senhora de Oliveira e outras igrejas da região de Guimarães. Braga.

Soares, F.N. (1989). Catolicismo, Sociedade e Moralidade no Final do Antigo Regime. Visitações de Salamonde (1750-1831). Cadernos do Noroeste 2 (2-3):217-260.

Soares, F.N. (1996). Sociedade, Criminalidade em Santa Eulália Antiga de Fafe (1548-1831). In Actas das Primeiras Jornadas de História Local. Fafe: Câmara Municipal de Fafe.

Vale, Pe. M.F. (1997). Visitas Pastorais à Paróquia de São Miguel de Vila Boa, nos séculos XVI e XVII. Brigantia. Revista de Cultura. Bragança XVII (1/2):109-118.

Vasconcelos, M. da A.J. (1986). Inventário das visitas e devassas. Braga: Universidade do Minho e Arquivo Distrital.

Artigo originalmente apresentado no $\mathrm{V}$ Congreso Internacional de La Población (Asociación de Demografía Histórica). Logroño - Espanha, 1998, na sessão "Matrimonio y nupcialidade: perspectivas interdisciplinares"; versão primeira publicada nos anais do mesmo congresso. 